Hilde R. H. de Geus

Michiel G. H. Betjes

Jan Bakker

\section{Neutrophil \\ gelatinase-associated lipocalin clearance during veno-venous continuous renal replacement therapy in critically ill patients}

Accepted: 18 July 2010

Published online: 19 August 2010

(C) The Author(s) 2010. This article is published with open access at

Springerlink.com

Dear Editor,

Predicting recovery of renal function in patients with acute kidney injury (AKI) supported with renal replacement therapy (RRT) is one of the top ten questions in the field of current AKI research. However, defining renal recovery and accordingly the best time for discontinuation of RRT is difficult, as reliable biomarkers are lacking.

The Beginning and Ending Supportive Therapy for the Kidney (BEST Kidney) study identified urine production $(>500 \mathrm{~mL} / 24 \mathrm{~h})$ as the best predictor for successful discontinuation of RRT [area under the curve (AUC) 0.81 ] in contrast to serum creatinine (SCr, AUC 0.64); however, its predictive value is severely confounded by the use of diuretics [1].

Neutrophil gelatinase-associated lipocalin (NGAL), a 25-kDa protein involved in iron transportation, is a potential tool for determination of initiation of RRT [2, 3]. However, once a patient is initiated on RRT, it remains to be elucidated how plasma NGAL concentrations will change.

To determine plasma NGAL clearance and sieving coefficient (SQ) during continuous RRT (CRRT), we measured prefilter and effluent NGAL concentrations in three subjects after informed consent was obtained. Patients were hemofiltered with zero fluid balance, $2 \mathrm{~L}$ postdilution mode in continuous veno-venous hemofiltration. Blood flow was set at $200 \mathrm{~mL} / \mathrm{min}$, and regional citrate anticoagulation was used. The filters were ethylene oxide (ETO)-sterilized Aquamax HF 19 with an in vitro cutoff point of $55 \mathrm{kDa}$.

NGAL levels were measured using a research-based enzyme-linked immunosorbent assay with detection limit of 10-4,000 ng/mL. NGAL clearance per minute was estimated using the assumed stable plasma concentrations during CRRT over the first $12 \mathrm{~h}$ and the calculated amount


Fig. 1 Temporal patterns of the prefilter plasma and effluent NGAL concentrations $(\mathrm{ng} / \mathrm{ml})$ in hours after initiation of continuous veno-venous renal replacement therapy in three individuals with anuric AKI 
of NGAL present in the total effluent. SQ was calculated by dividing the NGAL effluent concentration by the NGAL prefilter plasma concentration.

Three male anuric patients were studied (age 40-64 years). Their admission diagnoses were hemorrhagic shock, cardiopulmonary resuscitation, and multitrauma. Baseline $\mathrm{SCr}$ values were $0.57,0.66$, and $0.68 \mathrm{mg} / \mathrm{dL}$, with SCr at time of CRRT initiation of 3.7, 9.7, and $12.3 \mathrm{mg} / \mathrm{dL}$. Estimated median (standard deviation, SD) plasma NGAL clearance was 4.8 (1.89) $\mathrm{mL} / \mathrm{min}$ with median (SD) SQ of 0.147 (0.04). The prefilter and effluent NGAL concentrations are plotted against time in Fig. 1.

Normally, plasma NGAL is cleared through glomerular filtration and entirely processed by proximal tubular cells [4]. However, in case of AKI, plasma concentrations rise quickly, even when estimated glomerular filtration rate (eGFR) is still normal, and tend to decrease quickly when the injurious event subsides [5]. Therefore, NGAL might have potential to be an early indicator of renal recovery in critically ill patients supported by RRT.

Our results suggest that plasma NGAL is hardly cleared during continuous veno-venous hemofiltration.
A possible explanation lies in the fact that larger serum proteins effectively lower the passage of small proteins by forming a gel layer over the membrane pores.

In conclusion, we have shown that CRRT does not substantially influence plasma NGAL concentration and therefore does not need to be taken into account when kinetics of plasma NGAL levels are used as an indicator for persistent renal injury or renal recovery in hemofiltered critically ill patients.

Open Access This article is distributed under the terms of the Creative Commons Attribution Noncommercial License which permits any noncommercial use, distribution, and reproduction in any medium, provided the original author(s) and source are credited.

\section{References}

1. Uchino S, Bellomo R, Morimatsu H, Morgera S, Schetz M, Tan I, Bouman C, Macedo E, Gibney N, Tolwani A, Straaten HO, Ronco C, Kellum JA (2009) Discontinuation of continuous renal replacement therapy: a post hoc analysis of a prospective multicenter observational study. Crit Care Med $37: 2576-2582$
2. Cruz DN, de Cal M, Garzotto F, Perazella MA, Lentini P, Corradi V, Piccinni P, Ronco C (2010) Plasma neutrophil gelatinase-associated lipocalin is an early biomarker for acute kidney injury in an adult ICU population. Intensive Care Med 36:444-451

3. Bouman CS, Forni LG, Joannidis M (2010) Biomarkers and acute kidney injury: dining with the Fisher King? Intensive Care Med 36:381-384

4. Schmidt-Ott KM, Mori K, Li JY, Kalandadze A, Cohen DJ, Devarajan P, Barasch J (2007) Dual action of neutrophil gelatinase-associated lipocalin. J Am Soc Nephrol 18:407-413

5. Mishra J, Dent C, Tarabishi R, Mitsnefes MM, Ma Q, Kelly C, Ruff SM, Zahedi K, Shao M, Bean J, Mori K, Barasch J, Devarajan P (2005) Neutrophil gelatinase-associated lipocalin (NGAL) as a biomarker for acute renal injury after cardiac surgery. Lancet 365:1231-1238

H. R. H. de Geus (®) · J. Bakker Department of Intensive Care, Erasmus University Medical Center, H 324, PO Box 2040, 3000 CA Rotterdam, The Netherlands e-mail: h.degeus@erasmusmc.nl

\section{G. H. Betjes}

Department of Nephrology, Erasmus University Medical Center, Rotterdam, The Netherlands 